\title{
6. The ghost of Felix Culpa Adventures in the journalism education trade
}

\begin{abstract}
What is the most effective way to teach the realities of journalism to students? This article argues that the most effective model is the community newspaper, which provides students with the opportunity to learn how to write for their own community, but also to learn the fundamentals of running a news outlet, from selling advertising to liaising with printers. It also argues that the same lessons can be applied in the digital age to online news sites and to students who need to know how to keep themselves afloat as independent journalists. Drawing on 20 years' of experience teaching journalism in different countries, including Australia, Fiji and the United Arab Emirates (UAE), the article looks at what worked, what did not and what lessons can be learned for the future.
\end{abstract}

Keywords: journalism education, Felix Culpa, Four Winds, laboratory newspapers, The Coranto, The Mirror, student newspapers, student media, student press, Wansolwara

\section{PHILIP CASS \\ Unitec Institute of Technology, Auckland}

I think it would be fun to run a newspaper. - Citizen Kane

N 1904, the American newspaper magnate Joseph Pulitzer found himself defending the school of journalism he had recently endowed at Columbia University. He had been criticised because it was not sufficiently attached to the realities of journalism, irrelevant, theoretical and would serve no great purpose. Pulitzer declared that it was precisely his ambition to create a school of journalism where the journalists and editors of the future could be inspired towards the loftiest goals of their profession, untainted by the tawdry concerns of commerce. In ringing tones, he told the readers of The North American Review:

Not to teach typesetting, not to explain the methods of business management, not to reproduce with trivial variations the course of a commercial college. This is not university work. It needs no endowment. It is the idea of work for the community, not commerce, not for one's self, but primarily for the public, that needs to be taught. The School of Journalism is to be, in my conception, not only not commercial, but anti-commercial. It is to exalt principle, knowledge, culture, at the expense of business if need be. 
It is to set up ideals, to keep the counting-room in its proper place, and to make the soul of the editor the soul of the paper. (Pulitzer, 1904, p. 33)

Journalism educators have been fighting over how to best educate journalists ever since. There has been, at times, heated debate over the best method through which to inculcate the professional skills and attitudes necessary for journalists. I have always believed that journalism students learn best by doing as much as possible, by seeing their work in print, or online, or on air.

To adapt a phrase from Napoleon, I believe that every journalist carries in his or her knapsack the em rule of an editor. My aim in teaching journalism has been to provide students with the experiences and skills that will help them understand as many facets of newspaper production as possible so that they can be owner-operators, editors or freelancers who will survive. Even in a digital age, students who want to go into business for themselves as freelancers, trusted bloggers, vloggers or citizen journalists have to have some idea of the financial, professional and practical realities of keeping themselves afloat.

So I'm afraid that I part company with Pulitzer. It is wonderful to have lofty ideals and every journalism student should be instructed to believe in the highest professional standards of accuracy, probity and public duty. Unfortunately, if you cannot pay your printer, or the company hosting your web page or for your broadcasting license, then your lofty ideals will fall rather flat.

The method I have usually chosen to emulate is a community weekly. It is a model I am familiar with professionally and it seems to me to have all the attributes one needs: It is compact, certainly doable from a student point of view and it introduces to students a whole range of possible tasks from selling advertising to liaising with the printers to (at least in the pre-digital era) understanding what the people who handled our colour separations needed and why. It is also a model that emulates to a degree the high demands placed on writers and sub-editors.

However, one must acknowledge that not everybody is enamoured of this method of learning by doing. As Deuze (2006) points out, there are those for whom a laboratory newspaper, radio station or website 'is a costly waste of faculty time and resources, taking time and money away from teaching and research' (p. 29). This is especially so when the sceptics have never been journalists and they can pose a danger to such projects if they are allocating staff workloads or departmental resources.

Community newspapers, whether urban or rural, are where a great many journalists work and arguably demand more of journalists than elsewhere in the breadth of tasks required. As Hart (2001) notes, graduates who join a small country masthead often find they are expected to write, subedit, take pictures and do the layout.

In Australia, according to Cafarella (2016), trainee journalists may make up half of the editorial staff of community newspapers: 
producing up to 16 stories a week on anything from complex planning issues to golden wedding anniversaries. Lack of staff and resources mean that the loftier ideals of journalism often give way for the more practical issues of finding enough stories and dealing with pushy advertising representatives. (Cafarella, 2016, p. 7)

On a university campus, student media, of whatever kind, can become a vital part of the community, something very akin to the role of the media in suburban or rural communities.

It is no exaggeration to suggest that a local newspaper forms an organic part of a community's life. It usually serves an immediate need for various practical information as well as supporting a less tangible, even tacit, need for some confirmation of collective values. (Vine, 2001, p. 40)

Hapney (2013) argues that student newspapers fulfil a major social function, but also serve to educate journalism students about the realities of the industry:

The role of the student press is fourfold. First, it chronicles life on campuses by informing readers about events ranging from national, international, and local news to student protests, athletic events, and the like. Secondly, the press provides a forum in which students, faculty members, administrators, staff members, and others can debate issues of concern. Thirdly, it acts as a watchdog to uncover problems on campus such as crime and cafeteria health code violations. Fourth, student media are a training ground for a new generation of journalists... [ ] ...student newspapers play an important role as they report news, publish the opinions and discussions of members of campus communities, and may print advertisements of interest to students, faculty members, and others on their campuses. Budding journalists can improve their skills if they can enjoy the freedom needed to work as independent professionals. (Hapney, 2013, p. 116)

One element that has always driven me and which never seems to be mentioned in textbooks or journal articles, is that teaching these skills needs to be fun. The students must be enthused, happy and willing to work long hours - and so must the staff. You are all working together towards a common goal and if you are with an enthusiastic team that is clearly engaged, who regard themselves and what they are doing as something special, then it will work.

As technology and resources have changed, so have the outlets for student work. The practical needs, however, have not. Students who aspire to work for themselves or to set up independent online news outlets online will need to understand something of the technology and face the same reality of having to pay for services. And whatever the technology or the outlet, the requirement for well written, honest, balanced, news never changes. 
This article tells, in a series of vignettes, my own experiences of teaching journalism in various places around the world through student media. This has mostly been through community newspapers and reflects the arguments made above. Sometimes everything has gone splendidly. At others it has gone horribly flat. But at least I can hope that there are enough journalists who can aim to fulfil Pulitzer's loftiest ambitions and still understand that the ink and accountancy and technology he affected to disdain all play their part.

\section{Four Winds and Felix Culpa (CIAE, CQU)}

In the second semester of 1977, Dr Shelton Gunaratne, the journalism lecturer at what was then the Capricornia Institute of Advanced Education (now Central Queensland University) in Rockhampton, started a journalism student newspaper, Four Winds. In his unhappy recollections of his time at the CIAE, Gunaratne (2012) says his original plan was to start a weekly publication. It was a wildly over-ambitious scheme that was doomed to failure, for, as he noted, there were neither the institutional funds nor the willingness to support the project.

Gunaratne, perhaps inspired by ideas of independent student productions he had encountered during his studies in the United States, was constantly at loggerheads with departmental administrators and superiors he regarded as his intellectual and academic inferiors.

Four Winds, so named because the site of the campus has once been called Four Winds Hill, was subject to checking by the department

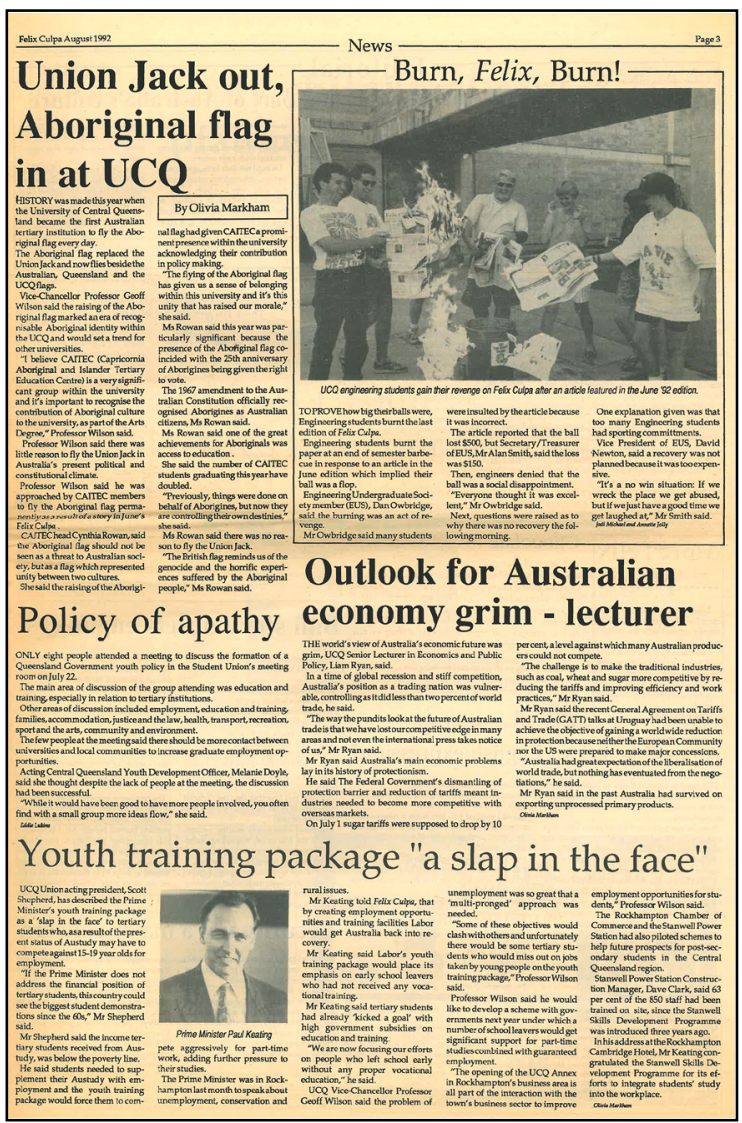

Figure 1: Felix Culpa and the situation got to such a level that I led a group of students to protest to the CIAE's director, Arthur Appleton. ${ }^{1}$ The publication struggled along for years, with sometimes two and sometimes three issues a semester, sometimes just a 
collection of pages stapled together with little regard for layout and design. After a decade of struggle, Gunaratne returned to the United States in 1985.

After filling Gunaratne's shoes with a series of short term replacements, the CIAE advertised for a journalism lecturer at the end of 1987. The Brisbane Express, for which I was chief writer, had closed without warning and I was painfully aware that a life of part time subbing on the Brisbane Courier-Mail would not feed my growing family. It was the height of the Fitzgerald inquiry into the rampant corruption of the Bjelke-Petersen regime and plenty of good stories were coming cross the subs' desk, but I needed a permanent job and applied to my alma mater. To my great surprise they offered me the job and so I returned to Rockhampton to teach journalism.

I discovered that Four Winds was still alive under the care of fellow former student turned academic, Liz Huf. Huf was a former Melbourne journalist and would later go on to launch the long running poetry magazine, Idiom 23 (CQUniNews, 2008). I gradually took over production of Four Winds and, acting largely on instinct, decided that it should fulfil bigger aims than just being a repository of student work.

I wanted the paper to become a tabloid. I wanted it to be in colour. I wanted it to be financially self-supporting and, if possible, make a profit. I wanted it to be a paper where the students would learn about every aspect of putting out a publication, from dealing with our printers in Gympie, to organising our colour separations with the repro house in Brisbane, selling ads, making editorial decisions, chasing down good stories and covering events on and off the campus and being as independent as possible. Unlike Gunaratne, I had no illusions about the administration's desire to wield a blue pen. I thought my job was to make them change their minds if necessary.

I wanted to produce journalists and people who could go off and start up their own newspaper, or walk into a newsroom and be able to turn their hand to pretty much anything. This was the age when desktop publishing had arrived and so, with a battery of Mac512Ks with tiny black and white screens and a copy of Pagemaker 1, we set out to make a newspaper. I decided we could make a real newspaper that would serve the needs of both the journalism course and serve the student community. We ran a state election special, covered campus issues, student union activities and did one sheet specials on graduation day so that students and families could have a souvenir issue on the day they graduated. It was on one of those graduation days that my former students claim that we actually produced the first online newspaper in Australia. We generally gave students at least a year's experience on the paper through two layout and design courses. From time to time we also affected changes on campus. It was an oddity that the three flags which flew outside the CIAE administration building were the Queensland state flag, the Australian blue ensign and the Union Jack. It was 
always felt the British flag was there because the Institute's director, Arthur Appleton, was British. However, when it continued to fly after his departure, one of my students asked Appleton's replacement whether it could not be replaced with the Aboriginal land rights flag. This was done almost immediately and it was a major symbolic change for the whole campus.

Being in Rockhampton was no barrier to covering the world. When Mount Pinatubo in the Philippines erupted in 1991, one of our students, who was on holiday in the country at the time, immediately headed there with camera ready and brought back a great story. Soon after the Soviet Union collapsed in 1989 I learned from a friend that a couple of tradesmen who had been working in Moscow had returned to Gladstone, about 70km south of Rockhampton, and we quickly arranged an interview and permission to use their photos of tanks in the streets of the Russian capital.

After a few years one of my students suggested that we rename the paper Felix Culpa. ${ }^{2}$ Meaning lucky fault or happy accident, it was a fairly good description of how we operated and it dealt with my long standing discontent with Four Winds as a name. Thereafter, we got a lot of mail addressed to Mr F. Culpa.

We did not always please everybody. A campus feminist group protested when we ran an advertisement for an ex-Penthouse model appearing at a nightclub popular with students and the engineering students demanded that we photograph them burning a pile of our newspapers in protest at a story we had run mocking them for running out of beer at a function.

The dean, David Myers, smiled benevolently upon us and signed off on our expenses without too much demur. However, as dean he was the final arbiter of what went in the paper, along with the head of the communication programme, Grahame Griffin. A system was already well entrenched when I arrived that they signed off the page proofs and when we changed our name to Felix Culpa we extended the Roman nomenclature by listing them as 'Imprimatur' and 'Nihil Obstat.'

My students had access to the journalism lab 24 hours a day and were familiar with the night time security staff. One of the female security staff was quite convinced that she had heard a shot being fired in the early hours of the morning and, since she was going through a very unpleasant break up with her partner, was convinced that he had shot at her.

The students got hold of the story before dawn and by the time I arrived at 9am they were all stirred up because the security guard's supervisor had arrived, found out what was happening, was annoyed, refusing to talk to my students and making it clear he would prefer nothing appeared. I went to see him and gradually persuaded him that the best thing he could do was to issue a statement. This he did, pointing out that it had been a stormy night, that nobody had seen anything and that the security guard could have heard a branch breaking. It may not have been the most dramatic response, but as I pointed out to him, my students had 
the story and if they did not get a response then it would spread to the cafeteria and the student bar and by nightfall people would be claiming that somebody had opened up with a machine gun. I got a statement and the students got a story.

Producing Felix Culpa was always fun and by the time we moved into our new lab, we were making a profit, so we moved things up a notch. We put in a second hand fridge, a video, TV, stereo, fold-out couches, our own fax machine and phone and the students blue tacked a barnyard full of plastic farm animals upside down to the ceiling so they could shoot them off when they got bored at $2 \mathrm{am}$.

I left for Papua New Guinea in 1994 to work on The Times of PNG and then moved to the University of the South Pacific in Fiji in 1995. Felix was carried on by my former student and successor, the late Jeff Young. Jeff, who died tragically in 2006, was a highly intelligent person and skilled journalist, who had run his own newspaper before joining the teaching staff (CQUniNews, 2006). Soon after Young's death, the Chair of Journalism Media and Communication at CQU, Professor Alan Knight left, and the journalism programme withered. Felix Culpa was gone.

Except that it wasn't, because thanks to the efforts of one of my former students, Dan Logovik, it survives as a Facebook group. Hence the title of this article.

\section{Wansolwara (USP, Fiji)}

At the beginning of 1995 I moved to Fiji where I joined the French-funded journalism programme run by the redoubtable François Turmel, formerly of the BBC. After a year I decided to start a student newspaper at USP. As I told The Fiji Times at the paper's 20th anniversary celebrations on 21 October 2016 :

When we started it, it was very much an experiment. We were doing it with inexperienced first-year students so it was a big learning process for all of us because even for me we were using digital photography, things I had never done before. (Susu, 2016)

David Robie (2004) has covered this period extensively in his own account

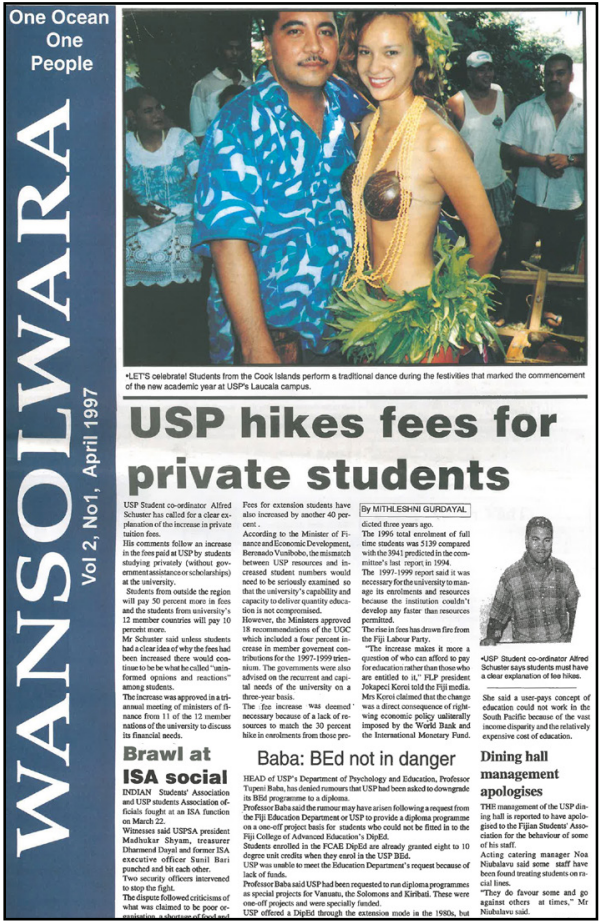

Figure 2: Volume two, issue one of Wansolwara. Note the vertical masthead. 
of his experiences teaching journalism in the Pacific, Mekim Nius. As I told him when interviewed in Suva in 2001 (quoted in Robie, 2004, pp. 179-181):

Common sense would have dictated that I start the paper with a second or third year group of students who were familiar with desktop publishing, but I felt that what was needed was a group of students who would stay with the paper for a few years and grow with it. I therefore decided that I would give the project to what was then the first year class ... [P]rogramme leader François Turmel gave his blessing to the project and persuaded the French Embassy to fund us.

We didn't actually have a name for the paper and the suggestion that we call it the Stanley Weekly was not met with complete enthusiasm by our first editor, Stan Simpson. However, it occurred to me that an expression I had heard in Papua New Guinea might be appropriate-Wansolwara.

Wansolwara expresses the idea that all of us who are born in or live in the Pacific are bound together by the ocean, whether our home is Fiji, Papua New Guinea, Tahiti, the Marianas - or even Australia and New Zealand! USP is home to students and staff from all over the great ocean, so Wansolwara seemed a perfect name. (Cass, quoted in Robie, 2004, p. 179)

Publishing the first edition was far from easy. In November 1996, the first edition came out. It was late, there were few advertisements and some technical problems were obvious. 'Our aim had been to strike a balance between campus news and a broader range of stories about issues affecting everybody in the Pacific. In the first issue, for instance, we had a piece on the use of skin lightening creams.' Later we dealt with issues, including 'the civil war on Bougainville, the role of fa'fine in Samoa and suicides in Fiji' (Cass, quoted in Robie, 2004, p. 179).

We had also begun to be noticed by the students. Our coverage of some questionable goings on at student functions and financial irregularities in the USP Students Association led to one of our staff, Mithleshni Gurdayal, being threatened - always a sign that our reporting was not only true, but causing embarrassment. (Cass, quoted in Robie, 2004, p. 181)

The success of Wansolwara as a teaching tool is best judged by how well students respond to the practical opportunities it offers and the entry to the work force which can flow from those experiences.

When David Robie took over the journalism course at USP in 1998, he brought with him the experience of several years of running the journalism laboratory newspaper Uni Tavur at UPNG (founded by Ross Stevens with New Zealand aid at independence in 1975) (Robie, 2004, p. 123). Like Felix Culpa, Uni Tavur had been run along community newspaper lines, with advertising 
sold to cover costs (Robie, 1997). During his time at USP, Robie established an advertising regime to pay for printing and production.

Wansolwara has been arguably the most successful economic model for a training newspaper in the South Pacific region because it has been able to self-fund publication for the past decade and consolidate its publishing structure. (Robie, 2006, p. 28)

On 21 October 2016, Wansolwara marked its 20th anniversary as part of the USP journalism programme's awards night. Journalism student Chrisnrita Aumanu, who won the 2016 award as best Wansolwara editor, said: 'Wansolwara is a great news outlet, as it is a great platform for student journalists to put on paper what they have been taught in classrooms. Moreover, Wansolwara moulds budding journalists like us to write better stories each and every time with a sense of pride when we see our bylines' (Aumanu, 2016).

Head of Journalism Dr Shailendra Singh said USP students practised what he called 'real-time journalism' at USP. He told The Islands Sun (2016) the need for well-trained journalists had increased with the onset of social media and citizen journalism, especially in the face of continuing development problems in the region.

Of the students who worked on Wansolwara over the years, many have gone into prominent positions in journalism and the communications industry. According to The Islands Sun (2016), several head their own news publications or have held editorial positions and others are successful publishers. Possibly more importantly for the development of the region's media,

...many regional/international organisations that were previously held by expatriates are now filled by USP Journalism graduates. A number of them have become communication specialists and serve government and non-government organisations at national and international level. (The Islands Sun, 2016)

\section{The Coranto (Teesside University, UK)}

Between 1997 and 2000, I taught at Teesside University in the UK. Our course was run in a very shaky partnership with Darlington College of Technology, where the students already had a newspaper, The Badger. This was not printed, but was simply run off in black and white and the sheets put on the notice board. Before the collaboration - and the course - collapsed (even a last ditch meeting in a private box during a match at the Middlesbrough football stadium could not save the partnership), I managed to get out two editions of The Coranto at Teesside.

Printed in colour and relying largely on feature stories, this was never meant to replace The Badger, but to complement it by doing something quite different. 
Apart from the print edition, the students were required to make an audio version, which was broadcast on Alpha FM in Darlington. A cassette copy of the programme was produced for distribution to libraries. It was a fairly primitive attempt at a multi-media news outlet.

I had included a television news production module to the journalism programme, using the skills of a highly experienced freelancer. Students shot and recorded news bulletins in the university's media centre. If the journalism programme had continued, this would have been incorporated into The Coranto.

\section{Al Miror/The Mirror (Zayed University, United Arab Emirates)}

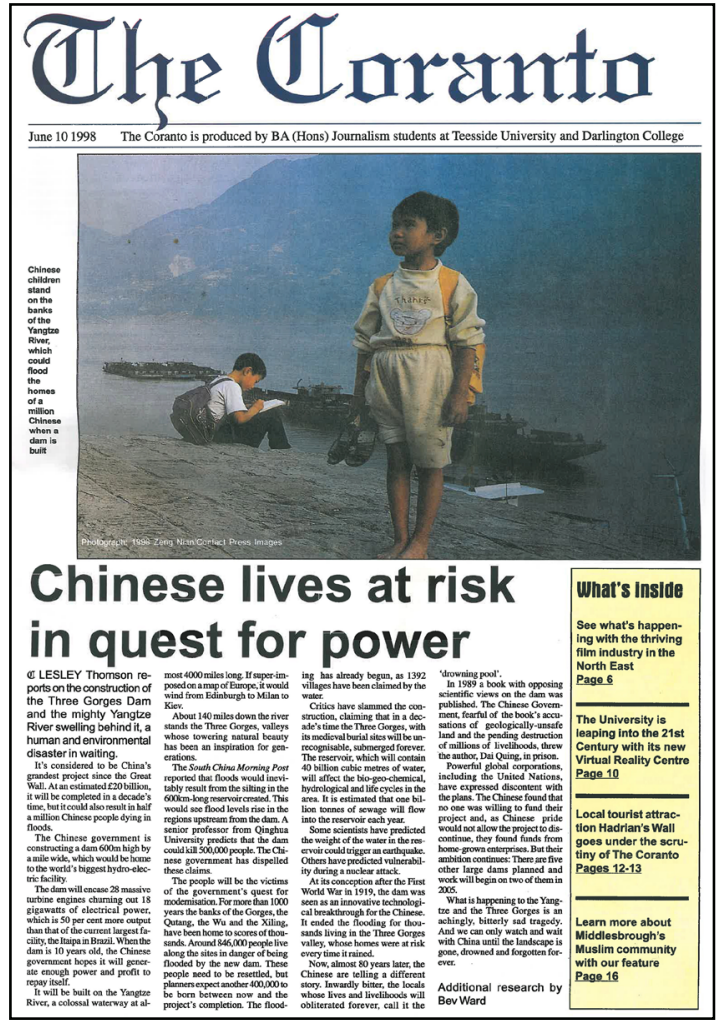

Figure 3: The Coranto

After Teesside, I moved to Zayed University (ZU) in the United Arab Emirates (UAE) at the end of 2000. The university was brand new, reflecting the vision of the country's president, Sheikh Zayed, for a university that would provide young Emirati women with a government-funded, Western-style, English-language education.

All our degrees had the word 'science' tacked on to the end of them to make them more acceptable to sceptical families, something that was especially necessary for parents who could not understand why anybody would want to study journalism and communication when these were clearly unsuitable jobs for young women. I taught in the College of Communication Science and taught journalism and newspaper layout and design.

My students produced a full colour glossy A4 publication for the UAE's national day celebrations in 2001 , so I decided to be more ambitious and produce a bilingual student newspaper. I thought this was a project that could not fail to ignite my students' interest and be attractive to the student readership.

I thought Al Miror/ The Mirror was a fabulous idea, but it just did not work. For a start, newspapers and journalism were not part of most of the students' 
cultural background. With few exceptions, they didn't read newspapers, watch or listen to news. Newspaper production in the UAE on any large scale dated back only to the early 1970 s and the press was, in any case, heavily censored. ${ }^{3}$

For the bulk of the students, news was simply not something that concerned them. Secondly, because of the general level of English, so much subbing had to be done on their stories that production progressed at a snail's pace. Thirdly, because of the way the campus and the culture operated, the students could only work on it in class. Students left at $5 \mathrm{pm}$ and did not work weekends. It took a year to get the first issue done and by that stage it was no longer a newspaper, but a collection of work from two different classes.

Eventually the paper was finished and went to the dean for approval. Then it ascended to much higher levels for approval and there it sat for more than a year and got old and grew whiskers and died. My colleagues on the Dubai campus had similar experiences when they tried to start a news magazine, although since theirs mentioned the invasion of Afghanistan, its demise was assured from the start. Eventually I became assistant dean in Abu Dhabi and was sucked into the vortex of administration and didn't teach journalism at ZU again.

Somebody else came along and produced The Mirror, an English language magazine with lots of stories about 'our field trip to Paris' and fashion tips. There was no further attempt to produce a bilingual publication.

My colleague Ed Freedman, a former CBS sports producer, had far more luck. He started ZUTV, which was streamed within the Abu Dhabi campus, the cultural mores of an all-female student population meaning it could not be seen anywhere else. Using a converted office painted bright blue as a set, the programme was immensely popular with the students involved.

As the Gulf News reported, ZUTV stories included:

...the National Day tribute paid to Shaikh Zayed, the Breast Cancer Awareness Campaign, a blood donation drive for thalassemia patients on Valentine's Day and German Chancellor Gerhard Schroeder's visit to ZU's Abu Dhabi campus.

The entire crew feels that working on the television programme is a great way to get hands on experience in broadcast journalism. It is also a good opportunity to meet high profile people and earn recognition for our work. (Nemer, 2005)

As Walters, Quinn, et al (2005, p. 63) pointed out, despite being very high consumers of media, our students spent as much time on the internet as they did in the combined activities of reading magazines, newspapers and books. This generation had effectively bypassed print altogether and gone to television and the internet. A serious bilingual newspaper must have seemed like a very dull proposition to all but the most dedicated and those with the best English. 


\section{After Gutenberg (Unitec, New Zealand)}

A recent publication from Griffith University in Brisbane notes:

Good communication skills are at the top of the list of what potential employers look for in graduates. The vast majority of business transactions involve written communication of some kind. Employers of graduates often express concern that students graduate with inadequate basic written communication skills. It is generally expected that university graduates have good literacy skills that can transfer into various work contexts, but research shows that this is not always the case. (www.griffith.edu. au/_data/assets/pdf_file/0004/290920/Written-communication.pdf)

These comments are even more pertinent for would-be journalists and anybody wanting to work in the communication industry. At Unitec, which I joined in 2010, we have only one journalism-type course, COMM6537 News Writing, which is offered in the Bachelor of Communication. Our degree concentrates on communication courses, but I strongly believe that any graduate benefits from learning the journalistic skills of interviewing, researching and synthesising information and presenting in a concise, readable, accurate form. It is also useful for PR hacks trying to get their 'sponsored' copy into print if they know what a real story looks like.

I revised the course extensively and like the proverbial quart into a pint pot, squeezed pretty much everything I could into it, from print to online to radio writing, ethics and the law. Students enrolled in the course are expected to produce five stories during semester and their work needed an outlet. Four of them are individual pieces while the final assignment is a group radio project. The course was highly praised by our external moderator from Auckland University of Technology in 2015.

In 2015, the radio work was done in-house, but this year we have been working with community radio station Planet FM on recording and uploading podcasts of the students' group radio projects.

At the end of 2015 I took over After Gutenberg, which had been run in fits and starts as a general student journal in the Department of Communication Studies at Unitec. I used it as a home for samples of the best student work in print, audio and online journalism. We managed one edition in 2015 which came out gradually over the summer under the banner After Gutenberg Summer Special.

The AG Summer Special consists of a front page with three links to a downloadable pdf A4 magazine that can also be read online, a selection of pieces that were designed to imitate the requirements of a very short online story accompanied by a photo and link to supporting material and links to YouTube where the radio group assignments were uploaded. Because the News Writing course does not have any design content, the $A G$ Summer Special was assembled largely 


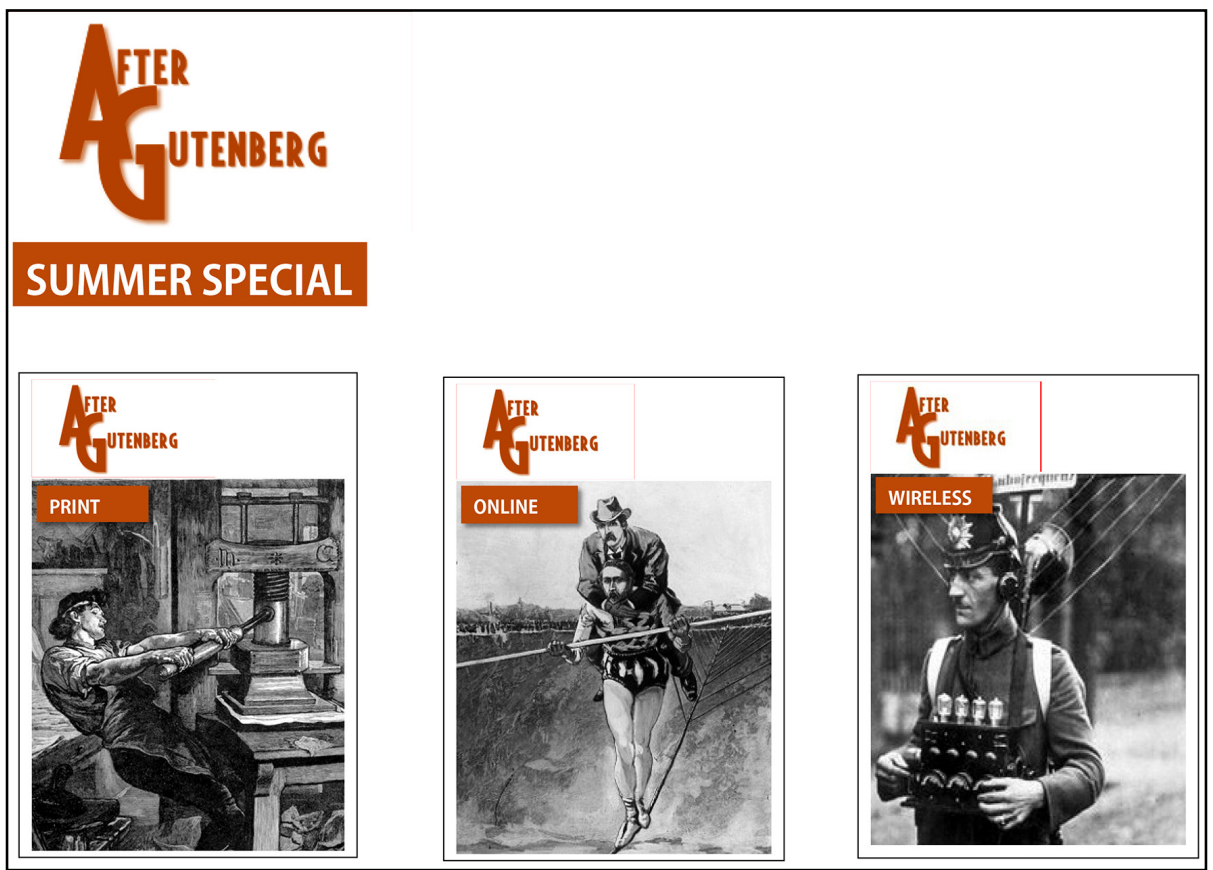

Figure 4: The After Gutenberg front page.

https://ia600204.us.archive.org/18/items/AGConsolidatedVerFeb2016/AG\%20Consolidated\%20 Ver\%20Feb\%202016.pdf.

by myself with help from our technical expert Mun Naqvi and help from two postgrad students, Anusha Bhana and Steve Ellmers.

As with everything else I have worked on over the years, the AG Summer Special was designed to showcase the students' work. For the moment, it cannot be anything else. News Writing only runs in second semester, there are no design courses and no way of giving students credit for working on the project. Because this is an introductory course, it means that we only generate a limited amount of usable copy and because the course has to teach the basics, that means essentially 10 paragraph stories rather than features.

In short, for the moment at least, After Gutenberg is tied to the course, not the other way round. We intend to use this format again in 2017, but with external links to Planet FM.

\section{Lessons learned}

After 20 years of producing student news outlets around the world, I have learned some lessons that might be useful for anybody attempting the same thing:

1. The first and most obvious is that there is no point in having students producing stories unless they have an outlet. That outlet must be visible and tangible and not look like just another classroom exercise. 
2. Any product must be able to cover campus news and larger events and appeal to a target audience. Remember The Mirror magazine? I hated it. The students loved it.

3. Journalism and student media production is very culturally specific, even when it is a country that speaks the same language as you.

4. Students must be given the opportunity to experience as many facets of media production as possible. This means they should do anything and everything that gives them a full understanding of what makes the medium work. Besides writing (or recording or shooting video or creating websites) that means selling ads and knowing as much as you can about the production side.

I have had students who have gone on to work for some of the biggest media outlets in the world - and some of the smallest — along with freelancers and PR people and book editors and producers. I like to think the experience of working on Felix Culpa or Wansolwara or The Coranto went some way to putting them there.

Students can indeed work online and never have to meet, but I have found that having one place to call their own is important. It helps create a centre point for the project and the esprit de corps that is essential to keeping a student publication going.

And finally, make sure you have at least one staff member crazy enough to devote the hours to the supervision and encouragement needed to make it all work.

\section{Notes}

1. Quite why I became so concerned, I do not know. While I was a journalism student I devoted my energies to the irregular production of the student union publication, Sensorium, which had nothing to do with news. It contained long rants about the evils of the fascist Bjelke-Petersen regime, spoof ads, satire, hand drawn stencils of flowers and birds and lots of stuff we stole from Monty Python and National Lampoon and was run off on a Gestetner in the dead of night by a tiny cabal of hairy students. It was much more fun.

2. The name means Lucky Fault and derives from the writings of St Augustine, particularly as used in the paschal vigil mass: 'O felix culpa quae talem et tantum meruit habere redemptorem.'

3. In fact newspapers in the UAE dated back to the 1920s and 1930s, something two students discovered for me when they found an Arabic book about the history of the local press and translated portions for me. (www.ejournalism.au.com/ejournalist/v1n2. html) 


\section{References}

After Gutenberg (2016). Retrieved from https://ia600204.us.archive.org/18/items/ AGConsolidatedVerFeb2016/AG\%20Consolidated\%20Ver\%20Feb\%202016.pdf.

Aumua, T. (2016, October 26). Top journo students honoured at USP's award night. Asia Pacific Report. Retrieved from http://asiapacificreport.nz/2016/10/26/top-journostudents-honoured-at-usps-award-night/

Cafarella, J. (2001). Training in the suburban newsroom. Asia Pacific Media Educator, $10,6-15$.

Cass, P. (2002). Newspaper archiving in the United Arab Emirates. E-journalist. Retrieved from www.ejournalism.au.com/ejournalist/v1n2.html

CQUniNews (2008, January 23). New edition marks 20 years of words and pictures. Retrieved from http://uninewsarchive.cqu.edu.au/uninews.cqu.edu.au/UniNews/ viewStory 8880 .html?story $=4796$

CQUniNews (2006, May 2). Jeff Young believed in journalism. Retrieved from http://uninewsarchive.cqu.edu.au/uninews.cqu.edu.au/UniNews/viewStory $83 \mathrm{f} 2$. html? story $=3204$

Deuze, M. (2006). Global journalism education: A conceptual approach. Journalism Studies, 7(1), 19-35.

Gunaratne, S. (2012). From village boy to global citizen: The life journey of a ournalist. XLibris.

Hirst, M., \& Treadwell, G. (2011). 'Blogs bother me': Social media, journalism and the curriculum. Journalism Practice, 5(4), 446-461.

Hapney, T. (2013). Student newspapers at public colleges and universities: Lessons from the United States. Education Law Journal (Spring), 114-124.

Hart, E. (2001). Journalism education and rural newspaper standards. Asia Pacific Media Educator, 10, 31-37.

Journalism programme hosts annual awards evening. (2016, November 1) Islands Sun. Retrieved from http://theislandsun.com/journalism-programme-hosts-annualawards-evening/

Pulitzer, J. (1904) The college of journalism. The North American Review, 178(570), 641-680.

Nemer, S. (2005, April 9). ZUTV, The Gulf News. Retrieved from http://gulfnews.com/ culture/education/zu-tv-1.283877

Robie, D. (1997). Electronic student newspaper: Uni Tavur and pedagogy of experience. Asia Pacific Media Educator, 2, 21-126.

Robie, D. (2004) Mekim Nius: South Pacific media, politics and education. Suva: University of the South Pacific Book Centre.

Robie, D. (2006). An independent student press: Three case studies for Fiji, Papua New Guinea and Aotearoa/New Zealand. Asia Pacific Media Educator, 17, 20-40.

Susu, A. (2016, October 23, 2016). Academic celebrates paper. The Fiji Times Online. Retrieved from www.fijitimes.com/story.aspx?id=375743

Vine, J. (2001). News values and country non-daily reporting. Asia Pacific Media Educator, 10, 38-48.

Walters, T., Quinn, S. R., \& Walters, L. M. (2005). Media life among gen zeds. International Journal of Cultural Studies, 8(1), 63-68. 
Dr Philip Cass is senior lecturer in the Master of International Communication programme at Unitec Institute of Technology, Auckland. He gave an address marking the 20th anniversary of the launching of Wansolwara student journalist paper at the University of the South Pacific, Suva, in October 2016. He is also one if the founding contributors, and currently associate editor and reviews editor, of Pacific Journalism Review.

cass.philip@gmail.com

\section{AUT COMMUNICATION STUDIES, TELEVISION \& SCREEN PRODUCTION}

A focus on real people to tell their stories

The ability to make exciting and innovative documentaries and screen productions that tell a good story is at the heart of undergraduate and postgraduate study at AUT.

The papers cover producing, directing, script writing, camera and sound recording, editing, production management and interviewing. They are taught by passionate, award-winning practitioners.

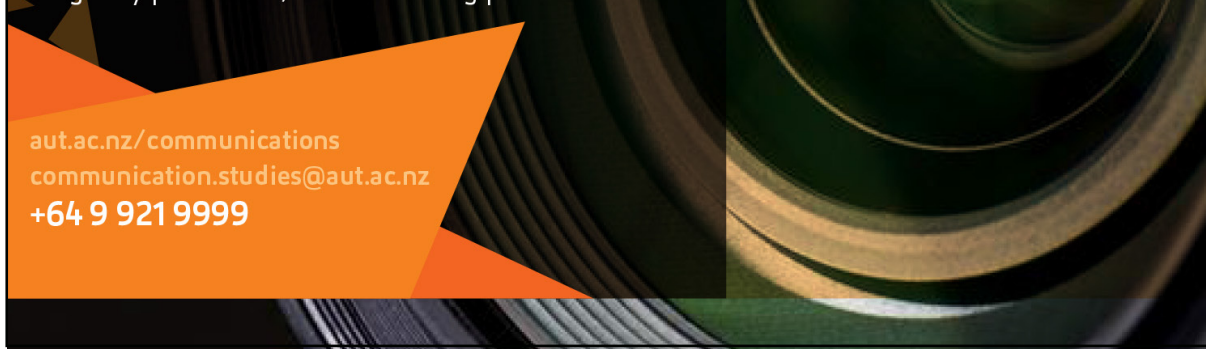

